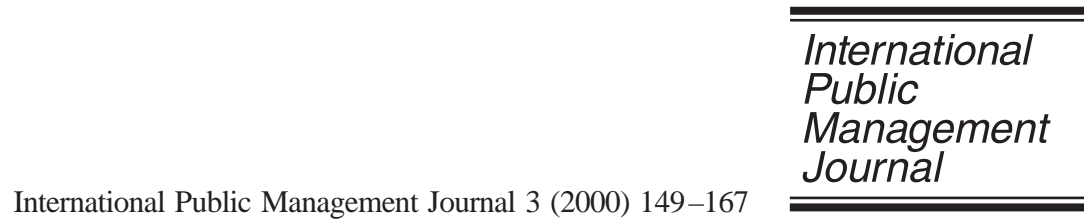

\title{
Managing for inclusion: balancing control and participation
}

\author{
Martha S. Feldman ${ }^{\mathrm{a}, *}$, Anne M. Khademian ${ }^{\mathrm{b}}$ \\ ${ }^{a}$ University of Michigan, Gerald R. Ford School of Public Policy, 454 Lorch Hall, 611 Tappan Street, \\ Ann Arbor, MI 48109-1220, USA \\ ${ }^{\mathrm{b}}$ Visiting Senior Fellow of the Robert A. Fox Leadership Program, University of Pennsylvania, Leadership \\ Hall, 3814 Walnut Street, Philadelphia, PA 19104
}

Received 12 September 1999; received in revised form 9 February 2000; accepted 20 September 2000

\begin{abstract}
Participation and control are both necessary in a democracy. In the two main models of public management, control trumps participation. The traditional model, Managing for Process, relies on centralized authority over process and emphasizes rules and regulations. The newer model, Managing for Results, permits decentralized control over process but relies on centralized control of results. We propose a third model, Managing for Inclusion, which has the potential to balance participation and control. Our model permits decentralized control over both process and results and requires centralized control over the implementation of participation. The tools of empowerment, teamwork, and continuous improvement take on new meanings in this model. We show how management tools such as training and rewarding can implement participation and control the process of inclusion. (C) 2001 Elsevier Science Inc. All rights reserved.
\end{abstract}

\section{Introduction}

Public management in a democracy engages a fundamental tension between public participation and hierarchy. This tension is unavoidable. Hierarchy is necessary to organizational effectiveness. Public managers must exercise control over processes, outcomes, or both to achieve public purposes and objectives (Kaufman, 1960). Citizen expectations of equitable treatment, fiscal prudence, and efficiency on the delivery of government services

* Corresponding author. Tel.: +1-734-764-6134.

E-mail addresses: msfeldma@umich.edu (M.S. Feldman), khademian@earthlink.net (A.M. Khademian). 
Table 1

Three models of managing participation and control

\begin{tabular}{|c|c|c|c|}
\hline & Description & Type of participation & Means of control \\
\hline Model 1 & $\begin{array}{l}\text { Centralized processes; Focus } \\
\text { on inputs rather than } \\
\text { results. }\end{array}$ & $\begin{array}{l}\text { Outside the organization in } \\
\text { political arena. }\end{array}$ & $\begin{array}{l}\text { Control exerted over compliance } \\
\text { with rules and regulations. }\end{array}$ \\
\hline Model 2 & $\begin{array}{l}\text { Decentralized processes; } \\
\text { Centralized results. }\end{array}$ & $\begin{array}{l}\text { In the management process, } \\
\text { but limited by emphasis on } \\
\text { results. }\end{array}$ & $\begin{array}{l}\text { Control exerted over } \\
\text { achievement of performance } \\
\text { targets. }\end{array}$ \\
\hline Model 3 & $\begin{array}{l}\text { Decentralized processes and } \\
\text { results; Centralized } \\
\text { responsibility for } \\
\text { implementing participation. }\end{array}$ & $\begin{array}{l}\text { In the management process, } \\
\text { considered essential for the } \\
\text { legitimacy and quality of } \\
\text { public work. }\end{array}$ & $\begin{array}{l}\text { Control exerted over } \\
\text { implementation of } \\
\text { participation through authority } \\
\text { to do such things as train, } \\
\text { reward and ask people to } \\
\text { account for their behaviors. }\end{array}$ \\
\hline
\end{tabular}

combine to heighten the importance of managerial control over public programs (Peters \& Savoie, 1996).

Two basic administrative models have been employed to meet the need for organizational control. We refer to these models as Managing for Process and Managing for Results. Table 1 summarizes these models as well as the third that we propose. In the first model, participation and control are assigned individual arenas. Participation is considered a political dimension, and political deliberation is employed to decide questions of policy. Once a policy is formulated, it is implemented with minimal discretion or input exercised by individuals throughout the organization. Administrative processes are strictly governed by rules and regulations defining who should complete a task, how it should be completed, and when. This is supposed to insure that policies, developed in the political arena, are brought to fruition. The primary role of top management in this model is to insure compliance with specified processes. In other words, authority is centralized and control is exercised ex ante (Thompson, 1991).

In the second model, Managing for Results, participation becomes part of the administrative arena by decentralizing authority in an organization. Public disappointment with government performance under the first model has prompted managers to find an alternative that places less emphasis on how work is accomplished, or the process, and greater emphasis on what is produced, or the results. In order to improve results in this model, managers rely on a decentralized distribution of authority to expand the range of ideas, priorities, and concerns used to solve problems. Under this distribution of authority, broader participation throughout the organization expands the possibilities of how the work is conducted, but individuals are expected to use their authority to achieve targets established by top management and political overseers. The primary role of top management is the establishment of performance targets and holding individuals accountable for achieving those targets. Control, in other words, is exercised ex post (Thompson, 1991).

Proponents of both of these systems of control have argued that the other is inherently undemocratic. The simple fact of the matter is that both groups are absolutely correct. These 
are both hierarchical as opposed to participatory systems. The only difference between them is the locus of top management's jurisdiction.

Yet, policy questions are rarely resolved once and for all through the legislative or judicial process. Instead, public problems and public policies are in a continuous process of adjustment to the changing needs and priorities of the public (Mazmanian \& Sabatier, 1983). In the current environment, for instance, definitions of public problems have changed as populations become more diverse and as private and not-for-profit organizations offer alternative means to address public problems. These conditions require a more fluid approach to the management of public resources and greater participation to increase the range of ideas, knowledge, and legitimacy of public efforts to address public problems. Public managers in a democracy therefore face the challenge of developing ways to allow for participation in the management of public resources by employees on the front lines as well as by the public (Reich, 1988; Ingram \& Rathgreb-Smith, 1993), while maintaining essential control.

In this paper we put forth a third model: Managing for Inclusion. We argue that public management models that emphasize either "process" or "results" fail to balance control and participation, and that ultimately this undermines the ability of public organizations to serve public purposes. We further suggest that making participation a meaningful part of a public management-control system requires decentralized control over both process and results. A basic premise of our model is that public policy unfolds in a dynamic environment in which a process, or the way the work of a public organization is accomplished, does not always produce the anticipated result. Therefore, while attention to process is important, specifying a particular process may have undesirable effects. Further, in a dynamic environment the pursuit of clearly specified results might not be the best approach as public problems change. Therefore, specifying particular results may be equally dysfunctional.

Given these assumptions, it follows that public managers must learn how to encourage employees as well as members of the public and participants in other relevant organizations to work in earnest toward results they may have little direct influence over. They do so using decentralized distributions of authority, as in the second model, with an emphasis on empowerment, teamwork, and continuous improvement to increase participation. In our model the focus of managerial control is on how managers implement participation. We conceptualize empowerment, teamwork, and continuous improvement as processes that call for different actions at different times. Managers exert control through their engagement in the process of defining and redefining how power will be shared, what teams are appropriate, and where improvement can be achieved. They use their authority to do such things as training, rewarding particular behaviors, and asking people to account for behaviors they engage in.

In the following sections we develop the models of Managing for Process and Managing for Results, and offer a critique of each. We then develop our model of Managing for Inclusion. We develop our model using examples of public managers whose techniques prompted our rethinking of the ways participation might be made a meaningful part of a controlled management system. Some of the examples are presented in published accounts, while others are taken from our own field research of local public managers. 


\subsection{Reconciling participation with control: two models}

Public managers face continuous pressure to be responsive to various economic and social interests and to allow greater access to decision making processes, yet the public holds them accountable for achieving broad public goals and resisting the demands of narrow interests that might detract from that mission. Systems of control are designed to insure that the work of individuals throughout an organization remain focused on public mandates. How these systems of control are designed influences how much and what kind of participation there is. In both the models that we describe below, we claim that control overwhelms participation.

\subsection{Managing for process: separating politics from administration}

In the United States, Woodrow Wilson (1887) and other public administration scholars (Goodnow, 1900; Gulick \& Urwick, 1937) suggested institutional arrangements that separate politics from administration as a means of achieving the dual demand for participation and control in democratic governments. This separation has developed into a powerful conceptual device: a politics-administration dichotomy. On one side of the divide are placed all things political: the desires, values, demands, and concerns of the public and their representatives, and the debates and communications that hone these concerns into statements of public interest. On the other side are placed all things administrative: the decision making and actions of the public administrator charged with implementing public policies in the most efficient manner possible. If the democratic challenge was an ability to delegate power to those with expertise crucial for serving the public interest, but limiting its use toward practices not deemed in the public interest, administrators could be checked by empowering only their administrative expertise (Friedrich, 1940). Even that expertise would be exercised within rules, regulations, and administrative structures established by political overseers and top managers defining various tasks, who was to complete them, and how they should be completed. Employee compliance with rules and regulations, in turn, became the primary concern for top management.

This dichotomy and its codification in forms of centralized distributions of authority has served the interests of both administrators and politicians by proposing simultaneously to strengthen the administrative capacity of government and to check administrative decision making to guard against constituent harm (see Knott \& Miller, 1987). The model, premised upon control over administrative processes to limit discretion, resonated with practitioners as a source of professional legitimacy. Administrators limited by procedures and the application of objective expertise could serve as conduits between the political world and the public, exercising expertise on behalf of the public interest (Landis, 1938; Freidrich, 1940). At the same time, limiting the discretion of public managers through ex ante controls has traditionally been understood as a way to decrease corruption and the dominance of parochial interests (Anechario \& Jacobs, 1996) and to ensure predictable service to the demands of constituent groups (Knott \& Miller, 1987). Indeed, the design of public organizations can be viewed as political choices to meet re-election priorities or the needs of constituent groups (Moe, 1990).

Despite the reasons that both administrators and politicians have for supporting gover- 
nance by process, there are considerable problems with it (Behn, 1998). First, participation is severely limited because of limited public access to and influence over administrative decision makers (Ostrom, 1973; Ingram \& Rathgreb-Smith, 1993). Institutional arrangements that maintain distance between public managers, the public, and the people with whom they work contribute to this lack of access. As Kweit and Kweit (1981) argue, "the effect ... [is] to insulate the bureaucracy and to decrease the impact of citizens on the implementation stage of decision making" (P. 81). Other scholars have focused on the disproportionate access these arrangements have given to organized interests and their resulting influence on public decisions (Lowi, 1969).

A second problem with managing for process is the role that leaders are able (or not able) to play in overseeing systems of procedural control and assuring their effectiveness. Woodrow Wilson (1887) argued that accountability for the actions of a public organization required the vigorous and visible exercise of administrative leadership. Effective administrative control, in other words, demanded effective leadership to exercise control. Yet some have noted that leaders have very little ability to affect what public organizations do beyond tweaking the tone of an organization and the attention it gives to particular priorities (Kaufman, 1981). The processes of administration, in other words, might take on a life of their own impervious to the efforts of appointed leaders. On the other hand, others have emphasized the unintended consequence of powerful and autonomous administrators, skilled in the use of objective decision making techniques and resistant to the efforts of chief executives and legislative bodies (Caro, 1975; Lewis, 1980; Rourke, 1984). Tough systems of procedural control have been used to legitimize the efforts of a leader to build power bases with public resources.

A third criticism of managing for process is the consequences for organizational performance. Some argue that public organizations are so bound by procedures, structures and analytical methods that they produce only confusion, stalemate, and public disappointment (Chubb \& Moe, 1990; Moe, 1990). The difficulties administrators face in siting toxic waste (Rabe, 1994), for example, or implementing clean air regulations (Weber, 1998) are increasingly traced to the application of structured procedures and decision-making efforts that distance administrators from the people affected by their decision making.

Criticisms are not limited to the academic world. Practitioners also note that these arrangements make it difficult for them to produce outcomes that satisfy the public. Rules that restrict the input to decisions are increasingly seen as obstacles to good public management rather than as safeguards. In practice, public managers have found that management practiced according to the process model can produce a great deal of public discontent (Gore, 1994; Osbourne \& Plastrik, 1997).

\subsubsection{Managing for results: focus on performance}

In response to these criticisms, reformers, practitioners, and scholars have sought a better way to conduct the business of government. While the variations on reform are vast (Kettl, 1997; Lynn, 1998), a common core is the decentralization of authority throughout public organizations in an effort to create better performance. The logic is that by extending discretion and decision making to a broader base of individuals, people can use the expertise they have developed by dealing with particular problems over time as well as their knowl- 
edge of context to develop solutions that work in particular situations. While this model eases ex ante restrictions on the way in which work is conducted, systems are designed to control behavior ex post by setting performance targets, or results, toward which empowered employees must work (Thompson, 1991).

This decentralized form of management increases participation and can improve performance. Organizations that decentralize authority in order to emphasize results in the public sector are cited for their enhanced innovation and performance (Barzelay, 1992; Osbourne \& Gaebler, 1992). Reformers around the globe report on improved performance (Boston et al., 1996), innovation (U.S. Department of Labor, 1996), changes in public sector culture (National Performance Review, 1997), and greater acceptance of public efforts (Rabe, 1994).

These benefits, however, may not be equally available to all agencies. The transition from managing for process to managing for results rests heavily on the political capacity to define the mandate, mission, and specific goals of an organization (Reschenthaler \& Thompson, 1998). Such specificity is easier for some government organizations than for others. For some agencies it is sufficiently difficult that observers wonder if a results orientation can ever serve as an alternative to the specificity of process in hierarchical systems (Behn, 1998). In its assessment of the British Next Steps initiative, a results-oriented reform effort initiated in the early 1990s, the United States General Accounting Office found that an emphasis upon results without clear definitions of mission and goals can lead to the pursuit of targets perceived by participants as irrelevant to the overall work of the organizations (U.S. GAO, 1997).

Even when the goals are well defined, the emphasis on performance may lead to a focus on what is measurable or easily measurable, rather than on outcomes consistent with the organization's mission. An EPA employee, for instance, describes the up- and downsides of a results-oriented approach. She recounts that in their efforts to reduce emissions, they have started to look more broadly at issues, such as city zoning, that affect how often or how far people drive their cars. Reducing the amount people drive would reduce emissions. Unfortunately, because it is difficult to demonstrate the results of these efforts, and because it is easy to demonstrate results from efforts to reduce "what comes out of the tailpipe," this latter work is considered more important in a results-oriented environment (interview by Martha S. Feldman, 29 December 1999).

Given these challenges, a concern with this model is that control might overwhelm participation, despite the language of decentralized authority. As in the EPA example, the potential of a more participatory management approach can be de-emphasized in favor of an approach that is more readily measured, and hence controlled. The employees working on the aspects of the problem that are not as easily measured or controlled, such as altering zoning practices as a means of reducing emissions, can feel marginalized because their work is not considered as important as the work that can be measured.

A more extreme assertion of control over participation would be the reversion to centralized control over process if managers were unable to set clear performance targets and use those targets as a means to control behavior. Critics of reforms based upon empowerment, teamwork, and continuous improvement argue that a "managerial meta-myth" continues to linger in organizations (Ingersoll \& Adams, 1992). These authors argue that managers continue to control for process even when they are practicing managing for results. If 
managers cannot control for results, for the reasons we listed earlier, they may feel they have no control option other than to control for process. Eventually the emphasis upon control exercised ex ante, and the importance of efficiency above all else, can suppress the empowered employee and the organizational commitments to improving the overall quality of the work effort (Hummel, 1994). In the next section, we present an alternative model aimed at finding a balance between control and participation.

\section{Managing for inclusion: an alternative model}

Both of the models discussed above rest on basic assumptions: that public policy goals can be specified clearly, and that the best way to go about achieving those goals is to use centralized authority to manage individual behavior in an organization. In both models the policy goals are defined centrally, but each model proposes different ways of managing individual behavior. In the first model, administrative processes are used to control the behavior of individuals responsible for bringing policy goals to fruition. In the second, the clear performance targets measuring progress toward public policy goals are the means to control behavior.

Three basic observations, however, prompt us to reject the assumption that there is any one way that is best to control behavior to produce clearly specified public policy goals. One is that it is not always clear how to get to a desired result. Processes that have worked in the past do not always work in the present. Processes that work in one place or for one topic do not always work in another (Boettger \& Greer, 1994). Given time, place, politics, and the nature of a task, ideal organizational methods may vary (Khademian, 1996; Wilson, 1989). The second observation is that the currently desired result does not always remain the desired result (Brunsson, 1989; March, 1978; Selznick, 1957). Preferences change for exogenous and endogenous reasons, and our understanding of public problems can change as different evidence, language, and ways of examining the problem are brought to bear (Gusfield, 1981; Stone, 1988). Finally, the pursuit of a particular result can have unintended consequences (Boettger \& Greer, 1994; Derthick, 1990). Control over either processes or results restricts the ability of participants to accommodate altered contexts, new preferences, and unintended results.

These observations suggest that it is difficult to have meaningful participation while maintaining centralized control over either the process or the results. Yet, if managers give up centralized control over both process and results, what control do they have left? We propose a model of managing for inclusion to answer this question. In our model, authority over both process and result is decentralized. Managers focus on building the capacity of their employees and the public to participate in the policy process. They practice empowerment and encourage teamwork and continuous improvement as means to build this capacity. They exert authority and control through the way they implement participation.

Our model is similar to the responsibilities Peter Senge (1990) assigns top managers in the "learning organization." Senge argues that the perception that any one manager or group of managers at the top of an organization is in control is an illusion. Even the smallest organization, he argues, is dynamic and complex, and while power might be concentrated at 
the top of the organization the capacity to control what happens throughout the organization is quite difficult, if not impossible. The alternative is a system of localized control where top managers become responsible for " $[\mathrm{u}]$ nderstanding the organization as a system and understanding the internal and external forces driving change" and the "learning processes whereby managers throughout the organization come to understand these trends and forces" (P. 299). In our model managing for inclusion, we argue that managers play a similar role. In this paper, we focus on the control that managers exert through their ability to define empowerment, teamwork, and continuous improvement as processes and to implement them accordingly.

An essential aspect of our model is conceptualizing the relationship between participation and control as a dynamic tension rather than a static equilibrium. One of the implications of our conceptualization is that the means of implementing participation are processes rather than outcomes or fixed forms. The dynamic quality of process allows managers to cope with the competing tensions of participation and control through constant adjustment rather than precise calculation. Three of the means of implementing participation are empowerment, teamwork, and continuous improvement. Each of these can be implemented as processes, allowing the manager to maintain some control over the process of participation. In the following we discuss what it means to implement empowerment, teamwork, and continuous improvement as processes, and we provide examples of managers exerting control over the implementation of participation through their authority to do such things as train and reward behavior.

\subsection{Empowerment}

Empowerment has been used to capture the notion of increasing the contributions of people who previously were not included in decision making, either by choice or by design (Osborne \& Gaebler, 1992; Osborne \& Plastrik, 1997). Empowerment has been associated with two different groups: employees throughout the hierarchy of bureaucratic organizations (Byham, 1998) as well as to citizens who traditionally have been marginal or silent (Ingram \& Rathgreb-Smith, 1993). Allowing greater participation in the decision-making process, it is argued, will allow new priorities to emerge. An example of this occurred in Oregon when the Department of Motor Vehicles embarked on improving customer satisfaction. Department managers thought their first priority should be to shorten waiting times. Customers, it turned out, were more interested in having better-looking pictures on their driver's licenses (National Performance Review, 1996). In both Grand Rapids, Michigan, and Charlotte, North Carolina, roads used to be designed by engineers with the efficiency of automobile traffic as the primary concern. Today in both cities communities design roads with engineers playing an advisory role. Communities decide how many lanes they want, whether they want sidewalks, median strips, and even if they want additional roads in the first place.

Empowerment raises two kinds of control problems. One is, how do managers make sure that really bad decisions are not made? The other is, how do managers convince those they empower that they really have the power to make decisions or to take action? These two questions are related. If managers maintain the ability to alter decisions that they think are really bad, then they undermine the belief that they will ever truly grant others their power. 
These problems are related to a zero-sum perception of power. This perception suggests that power, like an object, once given to another person cannot still belong to the giver. But power has interesting properties that make it unlike an object (Kanter, 1979; March, 1989; Pfeffer, 1981). There is not a fixed amount of power in a system. Power can, for example, be increased through use (Kanter, 1979; March, 1989). Furthermore, a manager's power can be increased by sharing it (Follett, 1924; Kanter, 1979).

Follett has distinguished between power over, power to, and power with (1940). One can have power over other people, power to make decisions or take actions, and power with others. Managers in a traditional bureaucratic organization have power over their employees or over decisions and actions that affect the public. It is possible to interpret empowerment as giving away the power over. Employees or members of the public are given power to make decisions and take actions. This version of empowerment suggests that either the manager has the power to or others do, but not both. An alternative understanding of empowerment is that it is the movement from power over to power with. In this form of empowerment, managers share power and use it very differently than when they have power over, but they do not give it away. Managers maintain the power to, but others have it as well. Empowerment, from this perspective, is sharing power rather than giving it away. It is about increasing the total amount of power in the system, not about decreasing the power of the manager. This sharing of the power to is fundamentally in the hands of the managers. Part of their job is to determine what power to share, with whom, in order to increase the capacity of the system. As situations change and as the abilities of individuals change, the efforts to empower will also change. This is what we mean by viewing empowerment as a process.

Managers who have this perspective on empowerment do not cede their power to their employees. They use their power to do such things as train people to engage in what they believe to be effective efforts and to reward people for their efforts. When employees have the power to, it is always understood that they are accountable to the manager for their actions. Take, for example, a police chief whose goal is to empower his officers to be problem solvers. His office has provided officers extensive training in what it means to be problem solvers and ways to be effective in this role. Beyond that, however, he comments that he needs to develop ways of documenting the officers' efforts as well as their outcomes. If he specifies what behaviors they are to engage in, they will not think for themselves and do what makes sense in a particular situation. If he specifies outputs such as crime rates or arrests or other measurable outcomes, he knows that there will be little incentive for his officers to engage in efforts to solve problems that have an indirect effect on crime. Yet, he believes that these efforts are important in the overall effort to make people feel more secure and ultimately to reduce crime. Therefore, he seeks direct control over neither process nor outcome. Instead, he seeks to have a system of documenting effort that enables him to know what efforts his officers are making and to reward them for effort rather than for outcome (Dennis Nowicky, interview by Martha S. Feldman, tape recording, Charlotte, NC, 11 November 1998). Moreover, while the boundaries may not be perfectly clear about what an officer can and cannot do in the pursuit of problem solving, there is no question that behaviors exist that are out of bounds.

Another example illustrates the limits on empowerment. A community development project in East St. Louis that is run by a team of university professors from the University 
of Illinois has empowered citizen leaders to contribute to the definition, development and implementation of community projects. The professors have even responded to the citizens' request to provide them with training that will make the citizens more capable participants. The result was the Neighborhood College, offering 30 hours of free university course work for more than 100 community leaders over a three-year period. But empowerment is practiced within parameters. A formal system is in place for approving projects funded with university money and staffed by faculty and hundreds of students. Faculty expertise serves to frame planning, redevelopment processes and, importantly, the educational experience of the Neighborhood College. Within these parameters, residents define, investigate, and analyze problems, generate priorities, and brainstorm solutions. The East St. Louis Area Research Project (ESLARP) priorities are neither imposed upon East St. Louis residents by faculty applying their expertise to community problems, nor generated entirely from within the community based upon experience, circumstance, and organizational capacity (Reardon, 1998). Instead, the "managers" have power with the citizens, resulting from the way they have practiced empowerment.

\subsection{Teamwork}

Teamwork can also be understood as the process of building the capacity of organizations or of networks through people working together. This understanding of teamwork puts the emphasis on the capacity that is built rather than on the individuals who are working together. The capacity that is needed may change over time even if the people involved do not change. Thus, our understanding of teamwork as a process is that there is a commitment to the idea of working with whomever is currently in a position to help the organization or network build the requisite capacity, rather than a commitment to working with specific people.

Teams of government employees working with employees of the private and nonprofit sectors have become commonplace (Smith \& Lipsky, 1993). In the United States, federal agencies partner with state and local agencies to enhance the effectiveness of particular policy areas (Radin, 1996). Teachers' unions partner with management in school districts and public universities to improve services to the public (U.S. Department of Labor, 1996). And police departments partner with mental health clinicians to improve the identification and treatment for children exposed to violence (Marans et al., 1995). Ideally, teams help managers to move the management process away from adversarial positions and efforts to protect the turf of an organization or department, and toward the identification of common goals that might be pursued with the benefits of more diverse information and greater resources.

Consider an effort to utilize teamwork by empowering traditionally excluded individuals and groups. In a number of places around the world, a new model for dealing with family violence is being tried. This model, referred to as Family Group Decision-Making, was first developed in New Zealand and had been used in Canada and the United States (Crampton, 1997; Pennell \& Burford, 1997; Rockhill, 1997). Central to this process is the inclusion of a broad range of people who have relevant interests in the welfare of the family, and particularly the children. For instance, in one process used in the United States, meetings about child maltreatment include the parents along with "other relatives, friends, neighbors, 
teachers, ministers and others" working "as a team to convene compact meetings during which the 'kinship' group develops a plan for the child's well-being" (Grand Rapids Foundation 1998: 26). The process is "innovative in that it shifts the role of child welfare professionals from making decisions about a child's future to supporting a family and community decision process" (Grand Rapids Foundation 1998: 26). The process mobilizes the resources of the family and community in an effort to provide the child with a safe and permanent home. The group, as a whole, develops a plan for the child. Use of this process has significantly lowered the number of children who have gone into foster care (Crampton, 1997). When this process works, children have safe homes and also stay connected to their family and community.

But this process also poses considerable risk. What if the team does not come up with a solution that benefits the child? Just as empowerment tugs at concerns for central control, so too does teamwork. Teamwork, as presented by the Family Group Decision-Making model, provides a means to empower participants, utilize diverse information, and ultimately produce outcomes that are better for the child. But the potential to produce outcomes that are worse for the child has to be acknowledged and constrained. It is the responsibility of the public manager to control the team process so that children are not abused or neglected.

The work of any team can be highly dependent on the group process (Gersick \& Hackman, 1990; Weick \& Roberts, 1993). While it is important for a team to work well together, Janis' (Janis, 1972) research on groupthink and Staw's (Staw, 1981) research on commitment escalation, for instance, has shown us that groups can work too well together to the detriment of public policy. Similarly, teams debilitated by personal conflicts and an inability to cooperate will not provide productive contributions to the policy process.

The benefit of teamwork is also dependent on the membership of the team. Teamwork that crosses institutional boundaries (within organizations, between organizations and across sectors) will not increase diversity of inputs if the team is not representative of the interests affected by team decisions. Consider the mission to protect the environment for the public. A team effort combining regulators, environmentalists, and business might reach agreement on a pollution prevention plan for a single factory or an entire industry, but might neglect consumer concerns or input. Concern for the inclusiveness of collaborative efforts and the possible resource inequities of participants for prolonged participation are criticisms of this use of teamwork for decision making within the U.S. Environmental Protection Agency (Amy, 1987).

Managers are responsible for producing strong public policy results in line with formal mandates. Hence, they face a challenge in utilizing teams in a manner that can facilitate, rather than inhibit, better efforts. Overcoming the limitations of groupthink and personal conflict, finding ways to create teams that represent relevant interests, and maintaining the team's focus on relevant problems are all part of this challenge. As in the case of empowerment, managers must find means to utilize teams that can engage the tension between central control and participation and find a means to balance these two demands.

We suggest that in order to achieve this balance, managers must move beyond paying attention to particular teams and particular team dynamics. We propose instead that they focus on developing commitment to the idea of team as well as to particular teams. This means that managers need to develop in their organizations a broad commitment to solving 
problems by working with other people across traditional boundaries. Employees need to be comfortable joining and leaving teams as well as working with a broad range of people. This type of commitment to teamwork can enable the manager to create teams that represent relevant interests and to shift participation in the team to maintain the team's focus on relevant problems.

If teamwork always depends upon the existence of personal relationships among team members or between the supervisors of team members, its use is tenuous at best. One manager in Charlotte, North Carolina, described the difference between teamwork before recently incorporated management changes and teamwork now. Before the management changes, effective teamwork depended on having developed a personal relationship with someone. "We had pretty good interdepartmental cooperation but it really depended upon a few people developing personal working relationships. For example, I had a real good working relationship historically with C. . R. . in engineering. So that tended to then permeate down into the organization. Previous transportation directors I could not develop a good working relationship with. .... You can't run an organization with 26 people in department head positions and expect that they can all develop interpersonal relationships [inaudible]. If you got $10 \%$ of us doing that you'd be lucky. . . . You can't spend all your time on relationships or you can't get your job done" (Martin Cramton, interview by Martha S. Feldman, tape recording, Charlotte, NC, 10 November 1998). The commitment has to be to the idea and the process of teamwork rather than to working with particular individuals.

Similarly, an administrator at a public university responsible for negotiating contracts with faculty, clerical, and technical unions on campus emphasized the essential role of a built-in process that brings traditional adversaries together as well as the individual commitment among all participants to the negotiations. There are times, he argued, when participants just don't have time to invest in the trust building exercises of information sharing and getting to know each other in formal and informal settings. The system will fail, he argued, if people are not committed to the process (Scott Hill-Kennedy, telephone interview by Anne Khademian, 19 November 1998).

How can managers bring about this commitment to the idea of teamwork? They can help to develop guidelines or rules of engagement that facilitate teamwork regardless of the individuals involved. Training in teamwork can provide a common base of understanding among organizational members. The use of teams with members of the public or other organizations might rely upon similar group process sessions to begin the process, with an understanding of and a commitment to the length of time that might be required to utilize teams effectively. Educating all participants on particular team techniques might require several group process sessions, and potential team members might need interactive time to overcome misunderstandings, biases, and prejudices through series of meetings. The routinization of techniques such as interest-based negotiations for dealing with conflict or problems can also provide guidelines for utilizing the value of teams while keeping institutional goals in mind (Fisher, Ury \& Patton, 1991; Susskind \& Field, 1996).

Within an organization, performance evaluation can also be used to create a commitment to the idea of teamwork. Often employees have to choose between a good performance evaluation and engaging in teamwork because evaluations focus on individual performance (Schein, 1996; Scholtes, 1993; Wise, 1996). Managers have found it problematic to assess 
the individual contribution to team outputs. Emphasis on the idea of teamwork and the willingness to serve on teams as needed can help to overcome this problem. The evaluation, then, is not on the team output but on the individual's understanding of and commitment to the appropriate use of teamwork as a way of solving problems.

\subsection{Continuous improvement}

Continuous improvement is a third means of building capacity. The creation of public value is a continuous process (Moore, 1995). The dynamic and uncertain environment of any policy area demands continuous efforts on the part of an organization to improve upon its mission (Drucker, 1990). Continuous improvement is an effort to enhance the existing level of performance primarily by looking for and creating new approaches (Cameron, Freeman \& Mishra, 1993). For the public manager, continuous improvement means testing and developing approaches continuously to find ways to improve upon the delivery of public goods and services, including the dimensions and processes of the organization and relationships between organizations that impact performance. Continuous improvement can take a variety of forms, not all of which involve participation. Some believe, however, that a critical dimension of this effort involves expanding the pool of information and the perspectives used for evaluating performance. Increased participation, often through empowerment and teamwork, is one way to bring about this expansion (Senge, 1990). For this reason we consider continuous improvement a response to the demand for greater participation.

Continuous improvement is an established part of project management within the East St. Louis Area Research Project (Reardon, 1998). Regular assessments of what the project has accomplished, the value of the contributions made by university participants and residents, and where the project ought to go next are built into the day-to-day functioning of the program. And the learning process is not limited to the activities in East St. Louis. Assessment of the contributions made by professional planners and architects, not only in East St. Louis but as professional groups responsible for training future professionals and making public contributions, also takes place (Reardon \& Shields, 1997).

Continuous improvement, however, creates a tension with individual and organizational needs for control. Scholars who describe learning organizations focus on the ways in which individuals participate in organizational efforts, their understanding of the organization's work, their participation on teams, and their power to contribute to the learning and mission producing process (Senge, 1990; Reschenthaler \& Thompson, 1998). Yet creating the conditions for learning cuts against inclinations toward risk aversion and the security that might come from limiting the authority to make decisions. These inclinations may be particularly strong when political demands for accountability are intense (Kettl, 1992). Take, for instance, the case of NASA after the moon landings. In their analysis of the Challenger space shuttle disaster, Romzek and Dubnick (1987) report that after the successful moon landings NASA found itself in a context of reduced political support and increased ambiguity about the goals they were seeking to accomplish. They argue that in this context NASA's process changed, from a highly decentralized approach to space exploration and travel in which scientists across the agency and country exercised a great deal of autonomy, to a more centralized form of decision making. The more centralized approach limited the opportuni- 
ties to innovate and, perhaps tragically, to bring errors and problems into the open through a more informal use of scientific teams. Yet, the more centralized approach represented the agency's need for control.

While innovation and risk taking can push an organization toward improvement in its mission, continuous improvement can also threaten the need for security among employees. Union and management leaders participating on committees to reform the police and fire services in Miami report the unsettling nature of continuous change throughout the organizations as a key factor limiting the utility of collaborative efforts to problem solve and reduce costs (Federal Mediation and Conciliation Service 1995).

For public managers applying continuous improvement, the challenge is to find a way to balance the more open and participatory processes that can lead to continuous improvement with the equally important demands for organizational and individual security and stability. Continuous improvement is clearly a process with no fixed end or output. This is integral to the tension created by continuous improvement. One reaction is to establish some fixed measures to use to judge improvement (Coe, 1999; Kopczynski \& Lombardo, 1999). This can thwart the effort toward continuity by placing the focus on achieving a certain level of performance rather than on learning and improving (Ammons, 1999). Yet without such fixed measure, how can managers promote continuous improvement as a means to build capacity and still provide some measure of stability for their employees and other stakeholders?

We suggest here that one way to respond to this challenge entails simultaneous attention to the long term and the short term. Balancing these two dimensions of time ensures that continuous improvement is a dynamic process and facilitates the integration of concerns for participation and concerns for outcome. In the short term there is always the need for providing measures of performance to employees, to politicians, and to the public. But short-term measures tend to cap performance. Attention to learning and improving over the long term can offset this tendency.

From this perspective, performance measures can be viewed not only as indicators of organizational performance at a particular time, but as indicators of what else an organization can do to better serve the public. Gearing performance measures toward less time bound future efforts can also be a protective dimension of institutional decision making, preparing constantly for what is to come. It requires suspending the belief that public problems can be "solved" with a particular plan or approach, and accepting the fluidity of public problems and the always imperfect efforts to address them. It also requires managers to find a balance between the need for benchmarks as measures of individual achievement, and the need to reward innovation and support failures made in good faith.

Performance evaluation is one way that managers can build this dual attention into the management process. Stanley Watkins, director of Neighborhood Services in Charlotte, North Carolina, described his efforts to create a performance evaluation system for his employees that motivates them to attend to both dimensions of time. The system combines attention to aspects of the job that are measurable in well-defined time units and aspects of the job that are not as well defined or as bounded in time. For most employees $70 \%$ of their evaluation is based on measurable performance of policy and program goals, another $10 \%$ on operational aspects of performance such as absenteeism, 10\% on leadership including teamwork and communication, and 10\% on career development For managerial employees, 
the evaluation based on policy and program goals was $40 \%$ and leadership was $40 \%$. The other figures were the same for all employees (Stanley Watkins, interview by Martha S. Feldman, tape recording, Charlotte, NC, 11 November, 1998). This system provides security for those who are risk averse or fear discrimination, but also provides a means of giving feedback about the quality of ongoing efforts.

\subsection{Critique of managing for inclusion}

Every model has its disadvantages. This one is no exception. In many ways our model brings us full circle by allowing for those outcomes that the first model was designed to guard against: individual abuse and corruption. Because individuals are provided much greater latitude in our model, they can also take advantage of their discretion. Not only can employees be abusive, but because the manager's evaluations are much more subjective than in the other models, managers can use their discretion in a discriminatory or abusive manner.

The police chief quoted earlier, for instance, pointed out that having empowered officers can create special problems:

I'll tell you how it does present problems is that a shrewd empowered officer can develop significant support in the community and then when we have to take action against him, that support comes out in his defense not knowing all the facts that we can't reveal to them. So we look like we're picking on this officer and we're not having family values, we don't have the community's concern in mind in removing officers they like, instead of thinking this officer's corrupt or abusing something or whatever. So that's one of the problems we have experienced. But, we have 1850 employees, it's going to happen (Dennis Nowicky, interview by Martha S. Feldman, tape recording, Charlotte, NC, 11 November, 1998).

Public management scholars have noted that efforts to stop corruption have often resulted in systems that have a greater (and negative) effect on performance than on corruption (Kelman, 1990: 11-28; Anechario \& Jacobs, 1996). The manager quoted above believes that centralized control does not stop abuse from happening and that an empowered work force does help prevent abuse because managers are more likely to find out if their employees are doing something that others consider to be wrong

I don't think [centralized control] is very effective. . . I mean, I don't think that all those negatives went away. ... It [abuse] may have been a little more subtle, but I don't think it was even more subtle. I think it was just as present, [but] . . the central decision maker didn't know about it. But that doesn't mean it wasn't going on. . . I think if you have an empowered organization there's more likelihood that [abuse] will be discovered early on, because people will be more willing to come forward and tell you about it (Dennis Nowicky, interview by Martha S. Feldman, tape recording, Charlotte, NC 11 November, 1998).

From his perspective, the culture of the organization has to have an "integrity component" that helps deal with abuses when they occur. The response to the problems of this model again requires the same use of authority required by our model itself. Management has an important role to play in creating and maintaining this integrity component, and the role is enacted through the authority managers have to control the process of participation: 
the way we treat people is really acting out our values, the way we select people, the way we train people, the way we evaluate people, all those things contribute to our culture. And I think our culture is the most powerful means of controlling the behavior of the officers and preventing their abusing their power. But that doesn't mean that everybody will do it right. . . (Dennis Nowicky, interview by Martha S. Feldman, tape recording, Charlotte, NC, 11 November 1998).

Managers who are managing for inclusion need to be aware of the potential for abuse by their employees. Similarly, systems that adopt management for inclusion need to be aware of the potential for abuse by management. Employees and management must be held to high standards and must both be able to account for their behavior.

\section{Conclusion}

In this paper, we propose a model that captures a different orientation to participation and control than has been suggested in previous management literature. We derive our model, in part, from the practices of managers we have interviewed and read about. We use the examples of their practices in an effort to understand how these managers are responding to the democratic demands to balance participation and control. We suggest that part of what they are doing is treating participation as a dynamic process over which they exert control through their implementation of empowerment, teamwork, and continuous improvement. This control is exerted through their use of such management prerogatives as training people, rewarding them for participation, and asking people to account for the behaviors they engage in.

\section{Acknowledgments}

The authors wish to thank Larry Lynn, Larry O'Toole, Steve Rathgreb-Smith and Ed Weber for comments on an early draft of this paper. We also thank Fred Thompson and anonymous reviewers for comments on a later version. We also thank many public managers for introducing us to the model we present here.

\section{References}

Ammons, David N. (1999). A proper mentality for benchmarking. Public Administration Review, 59(2), $105-109$. Amy, Douglas. (1987). The Politics of Environmental Mediation. New York: Columbia University Press.

Anechario, Frank \& Jacobs, James B. (1996). The Pursuit of Absolute Integrity: How Corruption Control Makes Government Ineffective. Chicago: University of Chicago Press.

Barzelay, Michael. (1992). Breaking Through Bureaucracy. Berkeley: University of California Press.

Behn, R. (1998). The new public management and the search for democratic accountability. International Public Management Journal, 1(2), 131-164.

Boettger, R. and C. Greer (1994). "On the Wisdom of Rewarding A while Hoping for B.” Organization Science, 5(4), 569-582. 
Boston, Jonathan, John Martin, June Pallot, Pat Walsh. (1996). Public Management: The New Zealand Model. Aukland: Oxford University Press.

Brunsson, Nils. (1989). The Organization of Hypocrisy: Talk, Decisions and Action in Organizations. New York: Wiley.

Byham, William C. (1998). Zapp! The Lightening of Empowerment. New York: Ballantine.

Cameron, Kim, Sarah Freeman and Aneil Mishra. (1993). "Downsizing and Redesigning Organizations." Pp. 19-65 in George Huber and William Glick, eds., Organizational Change and Redesign. New York: Oxford University Press.

Caro, Robert. (1975). The Power Broker: Robert Moses and the Fall of New York. New York: Vintage Books.

Chubb, John, Terry Moe. (1990). Politics, Markets and America's Schools. Washington, D.C.: The Brookings Institution Press.

Coe, C. (1999). Local Government Benchmarking: Lessons from Two Major Multigovernment Efforts. Public Administration Review, 59(2), 110-123.

Crampton, David. (1997). "Evaluating FGDM: What are the Expected Outcomes and How Can They Best be Measured. Part 2." Pp. 59-65 in 1997 National Roundtable Series on Family Group Decision Making, Summary of Proceedings.

Derthick, Martha. (1990). Agency Under Stress: The Social Security Administration in American Government. Washington, D.C.: Brookings.

Drucker, Peter F. (1990). Managing the Non-profit Organization: Practices and Principles. New York: Harper Collins.

Federal Mediation and Conciliation Service. (1995). "The Miami Story: The Pros and Cons of the Cooperative Process." In The FMCS Guide to Labor-Management Committees.

Fisher, Roger, William Ury and Bruce Patton. (1991). Getting to Yes. $2^{\text {nd }}$ ed. Boston: Houghton Mifflin.

Follett, M.P. (1924). Creative Experience. Toronto: Longmans, Green and Co.

Follett, M.P. (1940). "Power." Pp. 95-116 in Henry Metcalf and L. Urwick, eds., Dynamic Administration: The Collected Papers of Mary Parker Follett. New York: Harper.

Friedrich, Carl J. (1940). The nature of administrative responsibility. Public Policy, 1, 3-24.

Gersick, C.J. and J.R. Hackman (1990). "Habitual Routines in Task Performing Groups." Organizational Behavior and Human Decision Processes, 47, 65-97.

Goodnow, Frank. (1900). Politics and Administration. New York: Macmillan.

Gore, Al, Jr. (1994). The new job of the federal executive. Public Administration Review, 54, 317-21.

Grand Rapids Foundation. (1998). Helping the System Help Kids. Grand Rapids, Mich.

Gulick, Luther and L. Urwick (1937). Papers on the Science of Administration. New York: Institute of Public Administration, Columbia University.

Gusfield, Joseph R. (1981). The Culture of Public Problems: Drinking-Driving and the symbolic Order. Chicago: University of Chicago Press.

Hummel, Ralph. (1994). The Bureaucratic Experience. $3^{\text {rd }}$ ed. New York: St. Martin's Press.

Ingersoll, Virginia Hill, and Guy B. Adams (1992). The Tacit Organization. Greenwich, Conn.: JAI Press.

Ingram, Helen and Steven Rathgreb-Smith, eds. (1993). Public Policy for Democracy. Washington, D.C.: Brookings.

Janis, Irving R. (1972). Victims of Groupthink. Boston: Houghton Mifflin.

Kanter, Rosabeth Moss. (1979). "Power Failure in Management Circuits." Harvard Business Review (JulyAugust):65-75.

Kaufman, Herbert. (1960). The Forest Ranger: A Study in Administrative Behavior. Washington, D.C.: Resources for the Future.

Kaufman, Herbert. (1981). The Administrative Behavior of Federal Bureau Chiefs. Washington, D.C.: The Brookings Institution.

Kelman, S. (1990). Procurement and Public Management. Washington, D.C.: AEI Press.

Kettl, Donald. (1992). "Micromanagement: Congressional Control and Bureaucratic Risk." Pp. 94-109 in P. Ingraham and D. Kettl, eds., Agenda for Excellence: Public Service in America. Chatham, New Jersey: Chatham House Publishers, Inc. 
Kettl, Donald. (1997). The global revolution in public management: driving themes, missing links. Journal of Policy Analysis and Management, 16(3), 446-62.

Khademian, Anne M. (1996). Checking on Banks. Washington, D.C.: The Brookings Institution.

Knott, Jack and Gary Miller. (1987). Reforming Bureaucracy: The Politics of Institutional Choice. New York: Prentice Hall.

Kopczynski, Mary and Michael Lombardo. (1999). "Comparative Performance Measurement: Insights and Lessons Learned from a Consortium Effort.” Public Administration Review, 59(2), 124-134.

Kweit, Mary Grisez, and Robert W. Kweit (1981). Implementing Citizen Participation in a Bureaucratic Society. New York: Praeger.

Landis, James. (1938). The Administrative Process. New Haven, Conn.: Yale University Press.

Lewis, Eugene. (1980). Public Entrepreneurship: Toward a Theory of Bureaucratic Political Power: The Organizational Lives of Hyman Rickover, J. Edgar Hoover, and Robert Moses. Bloomington: Indiana State University Press.

Lowi, Theodore. (1969). The End of Liberalism: Ideology, Policy, and the Crisis of Public Authority. New York: W.W. Norton, Inc.

Lynn, Laurence E., Jr. (1998). A critical analysis of the new public management. International Public Management Journal, 1(1), 107-123.

Marans, Steven,. with the collaboration of Jean Adnopoz, Miriam Berkman, Dean Esserman, Douglas MacDonald, Steven Nagler, Richard Randall, Mark Schaefer, and Melvin Wearing. 1995. The Police-Mental Health Partnership: A Community-based Response to Urban Violence. New Haven: Yale University Press.

March, James G. (1989). Decisions and Organizations. New York: Basil Blackwell.

March, James G. (1978). Bounded rationality, ambiguity and the engineering of choice. Bell Journal of Economics, 9, 587-608.

Mazmanian, D. and P. Sabatier (1983). Implementation and Public Policy. Glenview, Ill.: Scott Foresman.

Moe, Terry. (1990). "The Politics of Structural Choice: Toward a Theory of Public Bureaucracy." Pp. 116-153 in O. Williamson, ed., Organization Theory: From Chester Barnard to the Present and Beyond. New York: Oxford University Press.

Moore, Mark. (1995). Creating Public Value: Strategic Management in Government. Cambridge: Harvard University Press.

National Performance Review. (1996). Vice President Al Gore's address to the Armed Forces Communications and Electronics Association Conference (February 13, 1996). Retrieved from the World Wide Web May 5, 1999: (http://www.npr.gov/)

National Performance Review. (1997). Serving the American Public: Best Practices in Customer-driven Strategic Planning. Federal benchmarking consortium study report. Washington, D.C.: National Performance Review.

Osborne, D. and T. Gaebler (1992). Reinventing Government: How the Entrepreneurial Spirit is Transforming the Public Sector. New York: Plume.

Osborne, D. and P. Plastrik (1997). Banishing Bureaucracy: The Five Strategies for Reinventing Government. New York: Plume.

Ostrom, Vincent. (1973). The Intellectual Crisis in American Public Administration. University, Ala.: University of Alabama Press.

Pennell, Joan and Gale Burford. (1997). "Evaluating FGDM: What are the Expected Outcomes and How Can They Best Be Measured. Part 1.” Pp. 49-58 in 1997 National Roundtable Series on Family Group Decision Making: Summary of Proceedings.

Peters, B. Guy, and Donald Savoie. (1996). "Managing Incoherence: The Coordination and Empowerment Conundrum." Public Administration Review, 56, 281-290.

Pfeffer, Jeffrey. (1981). Power in Organizations. Marshfield Mass.: Pittman Publishing.

Rabe, Barry. (1994). Beyond NIMBY: Hazardous Waste Citing in Canada and the U.S. Washington, D.C.: The Brookings Institution.

Radin, Beryl, ed. (1996). New Governance for Rural America: Creating Intergovernmental Partnerships. Lawrence: University Press of Kansas. 
Reardon, Kenneth. (1998). Enhancing the capacity of community-based organizations in East St. Louis. Journal of Planning and Educational Research, 17, 323-333.

Reardon, Kenneth, Thomas Shields. (1997). "Promoting Sustainable Community/University Partnerships through Participatory Action Research.” National Society for Experiential Education, 23(1), 1., 22-25.

Reich, Robert. (1988). The Power of Public Ideas. Cambridge: Harvard University Press.

Reschenthaler, G.B., and Fred Thompson. (1998). "Public Management and the Learning Organization." International Public Management Journal, , 1, 59-106.

Rockhill, Anna. (1997). “Oregon's Family Decision Making Study.” Pp. 47-48 in 1997 National Roundtable Series on Family Group Decision Making: Summary of Proceedings.

Romzek, Barbara and Melvin Dubnick. (1987). "Accountability and the Public Service: Lessons from the Challenger Tragedy." Public Administration Review, 47(3), 227-238.

Rourke, Francis. (1984). Bureaucracy, Politics, and Public Policy. 3rd ed. Boston: Little, Brown.

Schein, Edgar H. (1996). The three cultures of management: implications for organizational learning. Sloan Management Review, 38(1), 9-21.

Scholtes, P. (1993). Total quality or performance appraisal: choose one. National Productivity Review, 12(3), 349-362.

Selznick, Philip. (1957). Leadership in Administration: A Sociological Interpretation. New York: Harper and Row.

Senge, Peter. (1990). The Fifth Discipline: The Art and Practice of the Learning Organization. New York: Doubleday/Currency.

Smith, S.R. and M. Lipsky (1993). Nonprofits for Hire: The Welfare State in the Age of Contracting. Cambridge, Mass.: Harvard University Press.

Staw, B.M. (1981). The escalation of commitment to a course of action. Academy of Management Review, 6, 577-587.

Stone, Deborah. (1988). Policy Paradox and Political Reason. Glenview, Ill.: Scott Foresman.

Susskind, Lawrence and Patrick Field. (1996). Dealing with an Angry Public. New York: The Free Press.

Thompson, Fred. (1991). Management Control and the Pentagon: The Organizational Strategy-Structure Mismatch. Public Administration Review, 51(1), 52-66.

United States Department of Labor. (1996). Working Together for Public Service. Retrieved 11/30/98 from the World Wide Web: (www.dol.gov/dol/ sec/public/media/reports/Workingtogether)

United States General Accounting Office. (1997).. Performance-based Organizations: Lessons from the British Next Steps Initiative. Testimony, July, 8, 1997., GAO/T-GGD-97-151.

Weber, Edward. (1998). Pluralism by the Rules: Conflict and Cooperation in Environmental Regulation. Washington, D.C.: Georgetown University Press.

Weick, K.E. and K.H. Roberts (1993). "Collective Minds in Organizations: Heedful Interrelating on Flight Decks.” Administrative Science Quarterly, 38(3), 357-381.

Wilson, James Q. (1989). Bureaucracy: What Government Agencies Do and Why They Do It. New York: Basic Books.

Wilson, Woodrow. 1887. The Study of Administration. Political Science Quarterly, 2, 197-222.

Wise, Lois Recascino. (1996). "Enhancing Employee Performance.” Pp. 392-404 in James Perry, ed., Handbook of Public Administration. San Francisco: Jossey Bass. 